\title{
Enzymatic activity in azuki bean seedlings subjected to salinity and water deficiency
}

\section{Atividade enzimática em plântulas de feijão-azuki submetidas a salinidade e a restrição hídrica}

\author{
Mônica Satie Omura 1*; Gustavo Henrique Freiria2; Verônica Pellizzaro ${ }^{3}$; \\ Douglas Junior Bertoncelli ${ }^{1}$; Felipe Favoretto Furlan ${ }^{4}$; Eli Carlos de Oliveira ${ }^{5}$; \\ Lúcia Sadayo Assari Takahashi ${ }^{6}$
}

\section{Highlights}

Water stress promotes an increase in protein content in azuki bean seedlings.

Excess sodium in the soil solution decreases enzyme activity.

Potassium increases the production of antioxidant enzymes after salt stress.

\begin{abstract}
Salinity and water deficiency are factors that limit the initial development of crops, directly interfering with the efficiency of food production. Studies on the behavior of cultivable species under stress are important to determine management actions; therefore, the mechanisms involved in post-stress recovery should be investigated. The objective of this study was to evaluate the effect of water and salt stress on enzymatic activity in azuki bean seedlings. The experimental design was a completely randomized, $4 \times 6$ factorial arrangement (four reagents: $\mathrm{CaCl}_{2}, \mathrm{KCl}, \mathrm{NaCl}$, and polyethylene glycol 6000 (PEG 6000) $\times$ six osmotic potentials: $0.0,-0.2,-0.4,-0.8,-1.2$, and $-1.6 \mathrm{MPa}$ ). The quantification of protein content and analysis of enzyme (catalase, peroxidase, and phenylalanine ammonia-lyase) activity in seedlings were performed on the 10th day after sowing. $\mathrm{NaCl}$ is toxic and recovery of azuki bean seedlings was less likely under salt stress owing to reduced enzymatic activity. In contrast, seedlings subjected to $\mathrm{KCl}$ treatment showed increased production of antioxidant enzymes.
\end{abstract}

Key words: Antioxidant enzymes. Vigna angularis L. Water stress. Salinity stress.

1 Engos Agros, Drs. em Agronomia, Universidade Estadual de Londrina, UEL, Departamento de Agronomia, Londrina, PR, Brasil. E-mail: monica_omura@hotmail.com; dj_bertoncelli@hotmail.com

2 Prof. Dr., Universidade do Estado de Minas Gerais, UEMG, Unidade Ituiutaba, MG, Brasil. E-mail: gustavo.freiria@uemg.com

${ }^{3}$ Discente do Curso de Doutorado do Programa de Pós-Graduação Agronomia, UEL, Departamento de Agronomia, Londrina, PR, Brasil. E-mail: veronicapellizzaro@hotmail.com

${ }^{4}$ Eng $^{\circ}$ Agr $^{\circ}$, Dr., Instituto de Desenvolvimento Rural do Paraná, IAPAR, EMATER, Pitangueiras, PR, Brasil. E-mail: ffavorettofurlan@gmail.com

5 Pesquisador Dr., Omnia Brasil, Leme, SP, Brasil. E-mail: elioliveira.agro@gmail.com

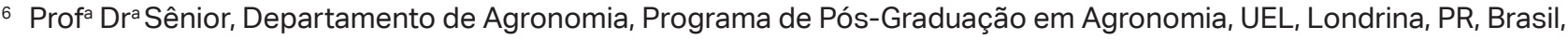
Bolsista Produtividade da Fundação Araucária. E-mail: sadayo@uel.br

* Author for correspondence

Received: Oct. 03, 2019 - Approved: Oct. 27, 2020 


\section{Resumo}

A salinidade e a restrição hídrica são fatores limitantes ao desenvolvimento inicial das culturas, interferindo diretamente na eficiência da produção de alimentos. Estudos sobre o comportamento das espécies cultiváveis sob estresse são importantes para determinar ações de manejo, por essa razão deve haver a investigação e compreensão dos mecanismos envolvidos na recuperação pós estresse. O objetivo do trabalho foi avaliar o efeito do estresse hídrico e salino sobre a atividade enzimática de plântulas feijãoazuki. O delineamento experimental utilizado foi o inteiramente casualizado, em arranjo fatorial $4 \times 6$ (4 reagentes: $\mathrm{CaCl}_{2}, \mathrm{KCl}, \mathrm{NaCl}$ e polietilenoglicol 6000 (PEG 6000) x 6 potenciais osmóticos 0,0; -0,2; -0,4; $-0,8 ;-1,2 ;-1,6 \mathrm{MPa}$ ). A quantificação do teor de proteínas e atividade das enzimas catalase, peroxidase e fenilalanina amônia-liase de plântulas foram analisadas no $10^{\circ}$ dia após semeadura. $\mathrm{O} \mathrm{NaCl}$ é tóxico e possibilita menores chances de recuperação em plântulas de feijão-azuki sob estresse salino devido a menor atividade enzimática. Por outro lado, as plântulas submetidas à solução de $\mathrm{KCl}$ apresentam aumento da produção de enzimas antioxidantes.

Palavras-chave: Enzimas antioxidantes. Vigna angularis L. Estresse hídrico. Estresse salino.

Azuki beans (Vigna angularis (Willd.) Ohwi \& Ohashi) are traditionally grown in Asian countries, and their use is associated with the food industry. The benefits of eating pulses are the provision of up to three times more protein than any cereal, in addition to the supply of other functional components. Awareness regarding these advantages has grown among populations and adherence to a healthy diet has gradually increased consumption (Liu et al., 2016).

Plants are susceptible to biotic and abiotic stresses. Among the limitations on the initial development of crops, salt stress and water deficit stand out; these interfere in metabolic processes and change the physiological and biochemical characteristics of cultivated plants (Złotek, Szymanowska, Baraniak, \& Karaś, 2015). To overcome stress, plants have the ability to modulate metabolic responses in order to return to the usual survival metabolism. When suffering oxidative stress, plants stimulate biosynthesis and intensify the activity of antioxidant enzymes, which is an important cellular signal for reactions of the plant defense system (Soares \& Machado, 2007). The increase in antioxidant enzymes reduces oxidative damage as the production and accumulation of reactive oxygen species, i.e., oxygen ions, peroxides, and free radicals, is obstructed (Zlatev \& Lidon, 2012).

According to Ahmed et al. (2014), studies that combine saltand water stress are of practical and ecological importance. When the limitations are at extreme levels, the success of cultivation is drastically reduced; therefore, to ensure adequate and targeted planning, it is essential to know the behavior of the genotype of interest in adverse conditions. Based on the above considerations, the objective of this study was to evaluate the effect of water and salt stress on the enzymatic activity of azuki bean seedlings.

The experiment was conducted under laboratory conditions at Londrina-PR. A completely randomized design was adopted, with four replications per treatment, arranged in a $4 \times 6$ factorial arrangement. The effects of water and salt stress on the enzymatic activity 
of azuki bean seedlings were evaluated by preparing four solutions: $\mathrm{CaCl}_{2}, \mathrm{KCl}, \mathrm{NaCl}$, and polyethylene glycol (PEG) 6000 adjusted to six osmotic potentials: $0.0,-0.2,-0.4,-0.8,-1.2$, and -1.6 MPa.

The concentrations were obtained based on the Van't Hoff equation, i.e., $Y_{\text {os }}=$ -RTC, where $\mathrm{Y}_{\text {os }}$ : osmotic potential (atm), R: universal gas constant (0.082 atm $\mathrm{L} \mathrm{mol}^{-1} \mathrm{~K}$ ), T: temperature $(\mathrm{K})$, and $\mathrm{C}$ : concentration $\left(\mathrm{mol} \mathrm{L}^{-1}\right)$ of treatment solutions as described by Villela, Doni and Sequeira (1991).

Four subsamples of 50 azuki bean seeds each, belonging to the phytotechnology seed bank of the State University of Londrina, were sown for germination between three sheets of paper moistened with the solutions to be tested, in the proportion of 2.5 times the mass of the dry paper. The rolls were kept in a Mangelsdorf-type germinator regulated at a temperature of $25^{\circ} \mathrm{C}$ for 10 days.

Each sample comprised $1 \mathrm{~g}$ of plant material (whole seedlings, except cotyledons) macerated in $20 \mathrm{~mL}$ of phosphate buffer $(0.2$ $\mathrm{M}$ and $\mathrm{pH} 7.5)$, and subsequently centrifuged at $12,000(\times \mathrm{g})$ at a temperature of $4{ }^{\circ} \mathrm{C}$ for 10 min. All analyses were performed in triplicate (Bertoncelli, Alamino, Oliveira, Marchesan, \& Loss, 2015).

Total protein was determined using the methodology proposed by Bradford (1976). The activity of the enzyme phenylalanine ammonia-lyase (PAL-E.C. 4.3.1.5) was evaluated using the methodology proposed by Umesha (2006) with some modifications. Seedlings ( $200 \mathrm{mg}$ ) were macerated in $2 \mathrm{~mL}$ of $\mathrm{pH} 6$ phosphate buffer, and then centrifuged at $6,000(\times \mathrm{g})$ at a temperature of $4{ }^{\circ} \mathrm{C}$ for $10 \mathrm{~min}$. Four hundred $(\mu \mathrm{L})$ of the supernatant fractions were removed and placed in tubes containing
$800 \mu \mathrm{L}$ of TRIS-HCl buffer $(0,5 \mathrm{M}, \mathrm{pH} 8.0)$ and $800 \mu \mathrm{L}$ L-phenylalanine (6 $\mu \mathrm{M})$ ). Subsequently, the contents of the tubes were homogenized and incubated at $37^{\circ} \mathrm{C}$ for $60 \mathrm{~min}$. The reaction was stopped by adding $100 \mu \mathrm{L}$ of $5 \mathrm{~N} \mathrm{HCl}$. Absorption readings were performed at 290 $\mathrm{nm}$ using a spectrophotometer Micronal AJX-1600. The enzymatic activity of PAL was expressed in $\mu \mathrm{g}$ equivalents of trans-cinnamic acid min $^{-1} \mathrm{mg}^{-1}$ of protein. Catalase (CAT) was determined by evaluating samples prepared with a solution containing $900 \mu \mathrm{L}$ of potassium phosphate buffer solution (0.05 $\mathrm{M}$ and $\mathrm{pH} 7.0)$ and hydrogen peroxide (12.5 mM), added to $100 \mu \mathrm{L}$ supernatant protein extract. Absorption was measured at $240 \mathrm{~nm}$ and a molar extinction of $36 \mathrm{mM}^{-1} \mathrm{~cm}^{-1}$ using a spectrophotometer (Anderson, Prasad, \& Stewart, 1995).

Peroxidaseactivity(POD) was quantified by converting guaiacol to tetraguaiacol by adding $900 \mu \mathrm{L}$ of solution containing $250 \mu \mathrm{L}$ of guaiacol, $306 \mu \mathrm{L}$ of hydrogen peroxide, and potassium phosphate buffer solution $(0.01 \mathrm{M}$ and $\mathrm{pH} 6.0$ to $100 \mathrm{~mL}$ ) in $100 \mu \mathrm{L}$ of supernatant protein extract. Data were recorded at 470 $\mathrm{nm}$ using a spectrophotometer (Lusso \& Pascholati, 1999).

The results were subjected to an analysis of variance (F-test). The treatment averages were compared using the Tukey test ( $p \leq 0.05$ ) for the qualitative factor (products) and the quantitative factor (osmotic potentials) was adjusted by orthogonal polynomials up to the second order using the statistical software $\mathrm{R}$ version 3.2.0.

Analysis of variance revealed that the interaction between the products and osmotic potentials was significant at the $5 \%$ probability of error level with the F-test for all evaluated characteristics. 
Protein content was high when the PEG 6000 treatment was applied with osmotic potentials of $-0.2,-0.4$, and $-0.8 \mathrm{MPa}$, and the last two potential levels, values did not differ from those of the $\mathrm{NaCl}$ and $\mathrm{CaCl}_{2}$ treatments. At potential levels of -1.2 and $-1.6 \mathrm{MPa}$, the highest protein content was with the $\mathrm{CaCl}_{2}$ and $\mathrm{KCl}$ treatments, respectively. Except for the osmotic potential of -0.4 MPa, the lowest levels were obtained when seedlings were subjected to $\mathrm{NaCl}$ treatment (Table 1).

The highest concentrations of the CAT enzyme were obtained with $\mathrm{CaCl}_{2}$ treatment at the potential of $-0.2 \mathrm{MPa}$, with PEG 6000 at -0.4 and $-0.8 \mathrm{MPa}$, and with $\mathrm{KCl}$ at -1.2 and $-1.6 \mathrm{MPa}$. In contrast, treatment with $\mathrm{NaCl}$ obtained the lowest averages at all potential levels, with the exception of -0.2 MPa, not differing from PEG 6000 at -1.2 MPa and $\mathrm{CaCl}_{2}, \mathrm{KCl}$, and PEG 6000 at -1.6 MPa. For the enzymes POD and PAL, the highest levels were found when $\mathrm{KCl}$ was used, regardless of the osmotic potential (Table 1).

Only the treatment with PEG 6000 increased protein content compared to that in the control $(0.0 \mathrm{MPa})$, with a maximum response point at a potential of $-0.31 \mathrm{MPa}$ with protein values of $9.89 \mathrm{mg} \mathrm{g}^{-1}$. In contrast, when the seedlings were in contact with $\mathrm{NaCl}$, the activities were not significant $(p>0.05)$ from -1.2 MPa (Figure 1).

For all enzymes, there was no significant ( $p>0.05$ ) adjustment to the regression analysis for PEG 6000; in the $\mathrm{NaCl}$ treatment, only POD was not significant. The CAT, POD, and PAL activities were intensified to the point of maximum response at potentials of -0.62 , -0.68, and $-0.18 \mathrm{MPa}$, respectively, for $\mathrm{CaCl}_{2}$ and $-2.41,-0.97$, and $-0.93 \mathrm{MPa}$, respectively, for $\mathrm{KCl}$ (Figure 1). 
Table 1

Protein content and enzymatic activity of catalase (CAT), peroxidase (POD), and phenylalanine ammonia-lyase in azuki bean seedlings in contact with $\mathrm{CaCl}_{2}, \mathrm{KCl}, \mathrm{NaCl}$, and polyethylene glycol (PEG) 6000 solutions at different osmotic potentials. Londrina, PR

\begin{tabular}{|c|c|c|c|c|c|c|c|}
\hline \multirow{3}{*}{ Products } & \multicolumn{6}{|c|}{ Osmotic potential (MPa) } & \multirow[b]{3}{*}{ C.V (\%) } \\
\hline & 0.0 & -0.2 & -0.4 & -0.8 & -1.2 & -1.6 & \\
\hline & \multicolumn{6}{|c|}{ Protein (mg g ${ }^{-1}$ tissue) } & \\
\hline $\mathrm{CaCl}_{2}$ & \multirow{4}{*}{$8.58^{* *}$} & $7.63 B^{*}$ & $6.63 \mathrm{~B}$ & $11.00 \mathrm{~A}$ & $11.45 \mathrm{~A}$ & $0.00 \mathrm{~B}$ & \multirow{4}{*}{14.57} \\
\hline $\mathrm{KCl}$ & & $4.20 \mathrm{C}$ & $4.24 C$ & $4.27 \mathrm{~B}$ & $4.38 \mathrm{~B}$ & $5.19 \mathrm{~A}$ & \\
\hline $\mathrm{NaCl}$ & & $7.19 \mathrm{~B}$ & $11.77 \mathrm{~A}$ & $2.00 \mathrm{C}$ & $0.00 \mathrm{C}$ & $0.00 \mathrm{~B}$ & \\
\hline \multirow[t]{2}{*}{ PEG 6000} & & $9.50 \mathrm{~A}$ & $10.55 \mathrm{~A}$ & $11.10 \mathrm{~A}$ & $0.00 \mathrm{C}$ & $0.00 \mathrm{~B}$ & \\
\hline & \multicolumn{6}{|c|}{$\mathrm{CAT}$ (mmol $\mathrm{H}_{2} \mathrm{O}_{2} \mathrm{mg}^{-1}$ protein) } & C.V (\%) \\
\hline $\mathrm{CaCl}_{2}$ & \multirow{4}{*}{$0.26^{* *}$} & $0.33 \mathrm{~A}$ & $0.44 \mathrm{~B}$ & $0.35 \mathrm{C}$ & $0.32 \mathrm{~B}$ & $0.00 \mathrm{~B}$ & \multirow{4}{*}{13.33} \\
\hline $\mathrm{KCl}$ & & $0.21 \mathrm{C}$ & $0.49 \mathrm{~B}$ & $0.57 \mathrm{~B}$ & $0.78 \mathrm{~A}$ & $0.82 \mathrm{~A}$ & \\
\hline $\mathrm{NaCl}$ & & $0.28 \mathrm{AB}$ & $0.35 \mathrm{C}$ & $0.04 \mathrm{D}$ & $0.00 \mathrm{C}$ & $0.00 \mathrm{~B}$ & \\
\hline \multirow[t]{2}{*}{ PEG 6000} & & $0.24 \mathrm{BC}$ & $0.78 \mathrm{~A}$ & $1.10 \mathrm{~A}$ & $0.00 \mathrm{C}$ & $0.00 \mathrm{~B}$ & \\
\hline & \multicolumn{6}{|c|}{ POD (UAbs min mg $^{-1}$ protein) } & C.V (\%) \\
\hline $\mathrm{CaCl}_{2}$ & \multirow{4}{*}{$0.04^{* *}$} & $0.27 \mathrm{C}$ & $0.31 \mathrm{~B}$ & $0.25 \mathrm{~B}$ & $0.13 \mathrm{~B}$ & $0.00 \mathrm{~B}$ & \multirow{4}{*}{15.65} \\
\hline $\mathrm{KCl}$ & & $0.48 \mathrm{~A}$ & $0.49 \mathrm{~A}$ & $0.51 \mathrm{~A}$ & $0.57 \mathrm{~A}$ & $0.45 \mathrm{~A}$ & \\
\hline $\mathrm{NaCl}$ & & $0.33 \mathrm{~B}$ & $0.21 \mathrm{C}$ & $0.07 \mathrm{C}$ & $0.00 \mathrm{C}$ & $0.00 \mathrm{~B}$ & \\
\hline \multirow[t]{2}{*}{ PEG 6000} & & $0.25 \mathrm{C}$ & $0.24 \mathrm{C}$ & $0.25 B$ & $0.00 \mathrm{C}$ & $0.00 \mathrm{~B}$ & \\
\hline & \multicolumn{6}{|c|}{ PAL (UAbs min m $^{-1} \mathrm{mg}^{-1}$ protein) } & C.V (\%) \\
\hline $\mathrm{CaCl}_{2}$ & \multirow{4}{*}{$0.14^{* *}$} & $0.12 \mathrm{~B}$ & $0.12 \mathrm{C}$ & $0.10 \mathrm{C}$ & $0.09 \mathrm{~B}$ & $0.00 \mathrm{~B}$ & \multirow{4}{*}{17.54} \\
\hline $\mathrm{KCl}$ & & $0.19 \mathrm{~A}$ & $0.23 \mathrm{~A}$ & $0.24 \mathrm{~A}$ & $0.27 \mathrm{~A}$ & $0.19 \mathrm{~A}$ & \\
\hline $\mathrm{NaCl}$ & & $0.11 \mathrm{~B}$ & $0.09 \mathrm{D}$ & $0.02 \mathrm{D}$ & $0.00 \mathrm{C}$ & $0.00 \mathrm{~B}$ & \\
\hline PEG 6000 & & $0.11 \mathrm{~B}$ & $0.18 \mathrm{~B}$ & $0.21 \mathrm{~B}$ & $0.00 \mathrm{C}$ & $0.00 \mathrm{~B}$ & \\
\hline
\end{tabular}

* Within column, means followed by a different letter differ significantly at $5 \%$ probability level by Tukey's Test.

${ }^{* *}$ Average corresponding to the osmotic potential $0.0 \mathrm{MPa}$ for all products.

For protein content, the enzymatic activity of CAT and PAL was lower when the seedlings were in contact with $\mathrm{NaCl}$ than that with the other treatments; the activities at potentials above -1.2 MPa were negligible (Figure 1).

Plants under stress produce reactive oxygen species in chloroplasts and mitochondria, i.e., superoxide radicals, hydrogen peroxides, and hydroxyl radicals, which act together or in isolation and catalyze oxidative damage that compromises the normal functioning of cells and plant growth (Soares \& Machado, 2007).

Plant defense mechanisms stimulate the biosynthesis and activity of non-enzymatic and enzymatic products with antioxidant power, such as CAT, POD, and PAL, to check oxidative stress (Farooq, Hussain, Walker, \& Siddique, 2015). This detoxification ability is essential and determined by morphological, physiological, and biochemical factors that 
have the objective of maintaining homeostasis and therefore, modulate the entry of salts through the roots and the production of osmoprotectors (H. Abbasi et al., 2016). a)

- $\mathrm{CaCl}_{2} \quad \hat{\mathrm{y}}=6,22^{\mathrm{ns}}$

- $\mathrm{KCl} \hat{\mathrm{y}}=7,276+8,178+4,453 \mathrm{x}^{2} \quad \mathrm{R}^{2}=0,73^{* *}$

- $\mathrm{NaCl} \hat{\mathrm{y}}=9,838+7,589 \mathrm{x}+0,4922 \mathrm{x}^{2} \quad \mathrm{R}^{2}=0,75^{* *}$

-. PEG $6000 \quad \hat{y}=9,202-4,372 x-6,993 x^{2} \quad R^{2}=0,76 * *$

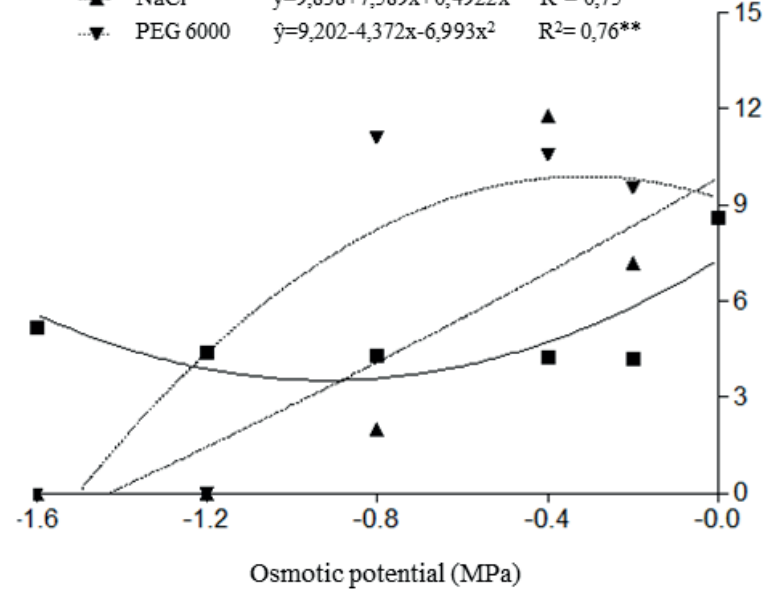

b) $\hat{y}=0,259-0,520 x-0,421 x^{2}$

$\because \mathrm{KCl}$

— $\mathrm{NaCl}$ $\hat{\mathrm{y}}=0,207-0,592-0,123 \mathrm{x}^{2}$ $\hat{\mathrm{y}}=0,323+0,288 \mathrm{x}+0,041 \mathrm{x}^{2}$

$\mathrm{R}^{2}=0,78^{* *}$

$\mathrm{R}^{2}=0,74^{* *}$

-. PEG $6000 \quad \hat{\mathrm{y}}=0,209^{\mathrm{ns}}$

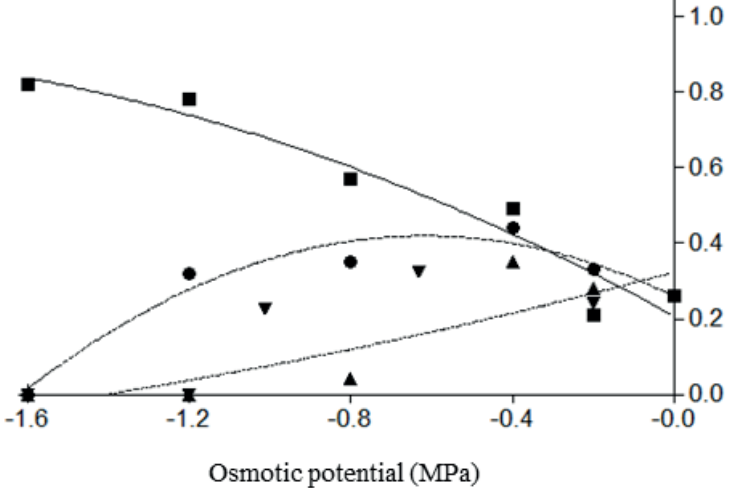

c)

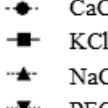

- $\mathrm{KCl}$

ॠ. $\mathrm{NaCl}$

$\hat{\mathrm{y}}=0,112-0,510 \mathrm{x}-0,376 \mathrm{x}^{2}$ $\hat{\mathrm{y}}=0,1583-0,924-0,474 \mathrm{x}^{2}$ $\hat{\mathrm{y}}=0,168^{\text {ns }}$

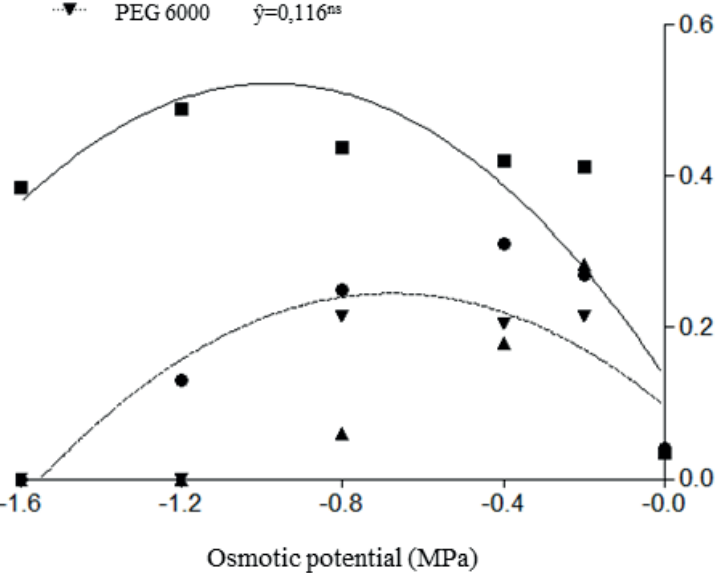

0.6

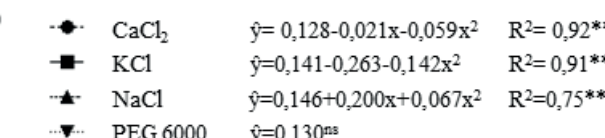

- $\mathrm{NaCl} \hat{\mathrm{y}}=0,146+0,200 \mathrm{x}+0,067 \mathrm{x}^{2} \quad \mathrm{R}^{2}=0,75^{* *}$

-. PEG $6000 \quad \hat{\mathrm{y}}=0,130^{\mathrm{ns}}$

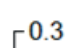

\section{3}

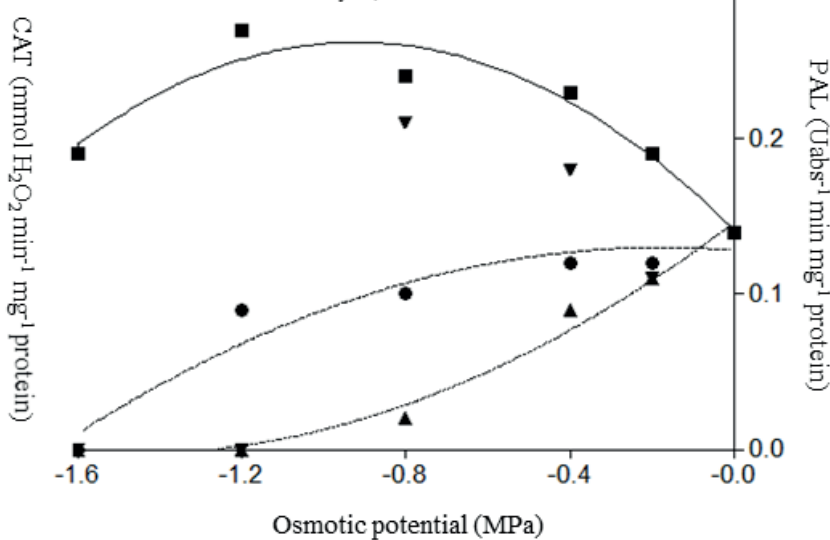

Figure 1. Protein content (a) and catalase (CAT) (b), peroxidase (POD) (c) and phenylalanine ammonia-lyase (PAL) (d) enzyme activity in azuki bean seedlings treated with $\mathrm{CaCl}_{2}, \mathrm{KCl}, \mathrm{NaCl}$, and PEG 6000 solutions at different osmotic potentials.

The activities of these enzymes increase during stress and are important to enable detoxification to mitigate the effects of oxidative stress (Zheng et al., 2008). The increase in activity and production of these enzymes could likely facilitate osmotic rebalancing in the presence of water and salt stress and the plant's recovery after hydration (Ahmed et al., 2014).

Water deficiency impairs the absorption and translocation of nutrients, and salinity promotes nutritional imbalance because $\mathrm{NaCl}$ 
is more soluble and abundant and competes with other ions, such as potassium, calcium, and nitrate (Munns \& Tester, 2008). Both stresses cause cell dehydration, damage to the membrane, reduced activity and denaturation of the cytosol and organelle proteins, and depending on severity, they cause the breakdown of cell metabolism (Mahajan \& Tuteja, 2005). This may explain the low values obtained in this study for protein and enzyme response levels when the interaction between the $\mathrm{NaCl}$ reagent and osmotic potential was investigated.

The relationship between sodium and potassium is critical for stress tolerance; the former competes directly with the latter for enzymatic sites, causing deficiency, and osmotic and water imbalance (Akham et al., 2010). Working on the tolerance of corn hybrids under salt stress, G. H. Abbasi et al. (2014), found that the tolerant varieties had a higher $\mathrm{K}^{+} / \mathrm{Na}^{2+}$ ratio than the sensitive ones: this implies the accumulation of potassium, an essential nutrient for the promotion of cell turgidity, because of the potentiation of water absorption by plants. These facts support the results obtained in the present study, in which the use of $\mathrm{KCl}$ enabled higher protein and enzyme content at the most negative osmotic potentials than those with the other solutions.

The relationship between the maximum limit of tolerated sodium and the imbalance of the $\mathrm{Na} / \mathrm{K}, \mathrm{Na} / \mathrm{Ca}$, and $\mathrm{Na} / \mathrm{Mg}$ ratios reduces plant growth and crop yield (Santos, Ruiz, Neves, Freire, \& Freire, 2009). Studies have shown that salt-tolerant cultivars tend to accumulate more potassium ions, and this condition increases the likelihood of survival of plants under stress. Therefore, adding this element to the saline solution could improve the growth of the aerial part and roots, potentiate the activity of antioxidant enzymes, and reduce the amounts of malondialdehyde, soluble sugars, and the electrolytic leakage in salt-sensitive cultivars (Zheng et al., 2008).

Su et al. (2012) found that saline stress containing silicon, potassium, and calcium ions increased the activity of the enzymes superoxide dismutase, CAT, and POD. Consequently, there was a reduction in oxidative cell damage and improvement in the recovery capacity of plants after rehydration when compared to a solution containing $\mathrm{NaCl}$.

In addition to the elimination of free radicals through enzymatic systems, plant metabolism has an effective mechanism for drought tolerance, i.e., the expression of stress-inducible genes that code and produce regulatory proteins, kinases, phosphatases, and aquaporins capable of minimizing the effects cellular dehydration (Krasensky \& Jonak, 2012). Therefore, the water stress caused by PEG 6000 triggered the increase in protein production.

The toxic nature of $\mathrm{NaCl}$ makes recovery of azuki bean seedlings less likely under salt stress owing to reduced enzymatic activity. In contrast, seedlings subjected to $\mathrm{KCl}$ treatment exhibited increased production of antioxidant enzymes.

\section{Acknowledgment}

We are grateful to the Coordination for the Improvement of Higher Education Personnel (CAPES) for the postgraduate scholarships granted and to the Araucária Foundation for the Productivity Scholarship in Research granted to Takahashi, L. S. A. 


\section{References}

Abbasi, G. H., Akhatar, J., Anwar-Ul-Haq, M. Ali, S., Cheng, Z. H., \& Malik, W. (2014). Exogenous potassium differentially mitigates salt stress in tolerant and sensitive maize hybrids. Pakistan Journal of Botany, 46(1), 135-146.

Abbasi, H., Jamil, M., Haq, A., Ali, S., Ahmad, R. Malik, Z., \& Parveen. (2016). Salt stress manifestation on plants, mechanism of salt tolerance and potassium role in alleviating it: a review. Zemdirbyste-Agriculture, 103(2), 229-238. doi: 10.13080/za.2016.103.030

Ahmed, I. M., Nadira, U. A., Bibi, N., Cao, F., He, X., Zhang, G., \& Wu, F. (2014). Secondary metabolism and antioxidants are involved in the tolerance to drought and salinity, separately and combined, in Tibetan wild barley. Environmental and Experimental Botany, 111(1), 1-12. doi: 10.1016/j. envexpbot.2014.10.003

Akham, M., Ashraf, M. Y., Ahmad, R., Waraich, E. A., Iqbal, J., \& Mohsan, M. (2010). Screening for salt tolerance in maize (Zea mays L.) hybrids at an early seedling stage. Pakistan Journal of Botany, 42(1), 141-154.

Anderson, D., Prasad, K., \& Stewart, R. (1995). Changes in isozyme profiles of catalase, peroxidase and glutathione reductase during acclimation to chilling in mesocotyls of maize seedlings. Plant Physiology, 109(4), 1247-1257. doi: 10.1104/pp.109.4.1247

Bertoncelli, D. J., Alamino, D. A., Oliveira, M. de C., Marchesan, E. D., \& Loss, E. M. S. (2015). Aspectos bioquímicos do desenvolvimento inicial de plantas de fisális sob diferentes condições luminosas. Brazilian Journal of Applied Technology for Agricultural Science, 8(1), 37-46. doi: 10.5935/PAeT.V8. N1.04

Bradford, M. M. (1976). A rapid and sensitive method for the quantitation of microgram quantities of protein utilizing the principle of dye binding. Analytical Biochemistry, 7(72), 248-254. doi: 10.1006/abio.1976. 9999

Farooq, M., Hussain, M., Wakeel, A., \& Siddique, K. H. M. (2015). Salt stress in maize: effects, resistance mechanisms, and management. A review. Agronomy for Sustainable Development, 35(2), 461-481. doi: 10.1007/s13593-015-0287-0

Krasensky, J., \& Jonak, C. (2012). Drought, salt, and temperature stress-induced metabolic rearrangements and regulatory networks. Journal of Experimental Botany, 63(4), 1593-1608. doi: 10.1093/jxb/err460

Liu, C., Fan, B., Cao, Z., Su, Q., Wang, Y., Zhang, Z., \& Tian, J. (2016). Development of a high-density genetic linkage map and identification of flowering time QTLs in adzuki bean (Vigna angularis). Scientific Reports, 6(39523), 1-10. doi: 10.1038/ srep39523

Lusso, M. F. G., \& Pascholati, S. F. (1999). Activity and isoenzymatic pattern of soluble peroxidases in maize tissues after mechanical injury or fungal inoculation. Summa Phytopathologica, 25(3), 244-249.

Mahajan, S., \& Tuteja, N. (2005). Cold, salinity and drought stresses: an overview. Archives of Biochemistry and Biophysics, 444(2), 139158. doi: 10.1016/j.abb.2005.10.018

Munns, R., \& Tester, M. (2008). Mechanisms of salinity tolerance. Annual Review of Plant Biology, 59(1), 651-681. doi: 10.1146/ annurev.arplant.59.032607.092911 
Santos, P. R., Ruiz, H. A., Neves, J. C. L., Freire, M. B. G. S., \& Freire, F. J. (2009). Acúmulo de cátions em dois cultivares de feijoeiro crescidos em soluções salinas. Revista Ceres, 56(5), 666-678.

Soares, A. M. S., \& Machado, O. L. T. (2007). Defesa de plantas: sinalização química e espécies reativas de oxigênio. Revista Trópica: Ciências Agrárias e Biológicas, 1(1), 9-19.

Su, D., Chen, N., Gao, T., Wang, C., Sheng, M., \& Yang, C. (2012). Effects of $\mathrm{Si}^{+}, \mathrm{K}^{+}$, and $\mathrm{Ca}^{2+}$ on antioxidant enzyme activities and osmolytes in halocnemum strobilaceum under salt stress. Advanced Materials Research, 356-360(1), 2542-2550. doi: 10.4028/www.scientific.net/AMR.356360.2542

Umesha, S. (2006). Phenylalanine ammonia lyase activity in tomato seedlings and its relationship to bacterial canker disease resistance. Phytoparasitica, 34(1), 68-71.
Villela, F. A., Doni, L., Fo., \& Sequeira, E. L. (1991). Tabela de potencial osmótico em função da concentração de polietileno glicol 6000 e da temperatura. Pesquisa Agropecuária Brasileira, 26(11/12), 1957-1968.

Zheng, Y., Jia, A., Ning, T., Xu, J., Li, Z., \& Jiang, G. (2008). Potassium nitrate application alleviates sodium chloride stress in winter wheat cultivars differing in salt tolerance. Journal of Plant Physiology, 165(14), 551465. doi: 10.1016/j.jplph.2008.01.001

Zlatev, Z., \& Lidon, F. C. (2012). An overview on drought induced changes in plant growth, water relations and photosynthesis. Emirates Journal of Food and Agriculture, 24(1), 57-72. doi: 10.9755/ejfa.v24i1.105 99

Złotek, U., Szymanowska, U., Baraniak, B., \& Karaś, M. (2015). Antioxidant activity of polyphenols of adzuki bean (Vigna angularis) germinated in abiotic stress conditions. Acta Scientiarum Polonorum Technologia Alimentaria, 14(1), 55-62. doi: 10.17306/J.AFS.2015.1.6 
